преобразования в авторскую интенцию: «И дума моя о нем - простая: вечный был труженик, добрый, честный человек» [4].

Итак, образ ребенка в рассказе В.М. Шукшина «Дядя Ермолай» функционирует в особых пространственно-временных координатах: то сливается с голосом взрослого рассказчика, то звучит как самостоятельное нарративное звено, актуализирующее ретроспективный план прошлых событий. Воспроизводя образ мальчика, особенности его речевой манеры, ощущения и эмоции, автор, с одной стороны, пытается вновь пережить впечатления прошлого, окунуться в мир детства, с другой - представить жизнь как цепочку взаимосвязанных жизненных эпизодов, раскрывающих судьбу отдельно взятой личности.

1. Зимин В. Я. Тема детства в творчестве К. Д. Воробьева: дис. ... канд. филол. наук. Курск, 2004. 192 c.

2. Николина Н.А. Повествовательная структура и жанр. М.: Прометей, 1993.

3. Большакова А.Ю. Феномен деревенской прозы (вторая половина ХХ века): дисс... д. филол. н. М., 2002. $403 \mathrm{c}$.

4. Шукшин В.М. собрание сочинений в 3-х томах. Т. 2. М.: Молодая гвардия, 1984.

\title{
Лядкина В.О., Курбанов И.А. \\ Особенности функционирования и перевода имен собственных на английском и русском языках (на материале произведения Клайва Льюиса «Последняя битва» и его переводов на русский язык)
}

Сургутский государственный университет (Россия, Сургут)

doi: $10.18411 / s p c-26-03-2018-06$

idsp: 000001:spc-26-03-2018-06

\section{Аннотация}

В статье рассматриваются проблемы функционирования и перевода имен собственных. На материале произведения Клайва Льюиса «Последняя битва» и его переводов на русский язык рассматриваются особенности перевода имен собственных с английского языка на русский язык.

Ключевые слова: имена собственные, антропонимы, топонимы, астронимы, переводческие трансформации, Клайв Льюис.

\section{Abstract}

The article considers the problems of functioning of proper names and their translation. The translation features of proper names of the novel "The Last Battle" by Clive Lewis from English into Russian are regarded in the article.

Key words: proper names, anthroponyms, toponyms, astronyms, translation transformations, Clive Lewis.

Сегодня общепринятым фактом является утверждение, что нет непереводимого в языке. Все единицы языка могут быть переведены на другой язык, если не прямо (лингвистические универсалии), то посредством приблизительного перевода, объяснений, лингвокультурологического комментария. Как правило, наибольшую трудность при переводе представляют слова, не имеющие прямого соответствия в переводящем языке по причине отсутствия в иноязычной культуре данного явления или предмета. Это так называемая культурно-маркированная лексика. Среди данной лексики выделяются имена собственные. 
Имена собственные служат для особого, индивидуального обозначения предмета безотносительно к описываемой ситуации и без обязательных уточняющих определений. Они выполняют функцию индивидуализирующей номинации.

Имена собственные изучает наука ономастика, раздел лексикологии. Разновидностей так называемых «онимов» существует очень много, однако в нашем исследовании мы описываем те имена собственные, которые встретились нам в нашем объекте исследования: антропонимы, топонимы и астронимы.

Антропоним - это имя собственное (или набор имён, включая все возможные варианты), официально присвоенное отдельному человеку как его опознавательный знак [3].

Антропоним называет, но не приписывает никаких свойств. Антропонимы обладают понятийным значением, в основе которого лежит представление о категории, классе объектов. Признаки данного значения:

- указание на то, что носителем антропонима является человек: James, Donald в отличие от Moscow, Danube;

- указание на принадлежность к национально-языковой общности: Eva, Mary, William в отличие от Ève, Marie, Wilhelm;

- указание на пол человека: Colin, Dylan в отличие от Lisa, Jennifer [1].

Топонимы как имена собственные обслуживают категорию географических объектов. [3] Современная топонимика активно развивается в направлении когнитивной лингвистики и лингвокультурологии. С этих позиций для исследователя представляет интерес не этимология топонима, а реальное восприятие его содержания членами данного языкового коллектива. Как отмечают Н. Д. Голев и Л. М. Дмитриева, при когнитивном анализе топонимов возникает иная точка отсчета - языковое сознание носителей языка, в котором функционируют данные топонимы [2].

Астронимы - имена собственные, обозначающие названия отдельных небесных тел. Астрономические названия используются для исследований в области ономастики и помогают определить специфику номинации объектов звездного неба, установить национальные особенности в процессе ономастической номинации. Астронимы в последние два-три десятилетия практически не изучались. Однако, вопросами и проблемами астронимики как науки все же занимались известные исследователи. Среди учёных-ономатологов известны работы В. А. Никонова, который небезосновательно считал этот класс онимов «ценным источником не только для лингвистических, но и для исторических раздумий и разработок». [5]

Наиболее распространенным методом перевода имен собственных являются переводческие трансформации.

В нашей работе мы делаем опору на классификацию Т. А. Казаковой, которая выделяетлексические, грамматические, синтаксические стилистическиепереводческие трансформации [4].

Для подробного изучения вопроса перевода имен собственных мы обращаемся к произведению Клайва Льюиса на английском языке «Последняя Битва» (“Thelastbattle”). В качестве перевода произведения «Последняя битва» с английского языка на русский язык были взяты варианты Ольги Борисовны Бухиной, Елены Михайловны Доброхотовой-Майковой, Владимира Георгиевича Тихомирова, известного под псевдонимом В. Воседой.

В ходе анализа перевода имен собственных с английского языка на русский язык, уважая труд переводчика, в некоторых выборочных случаях мы осмеливаемся предложить также и свой вариант перевода. 
Антропонимы

Имена

\begin{tabular}{|c|c|c|c|}
\hline Оригинал & $\begin{array}{c}\text { Перевод } \\
\text { О. Б. Бухиной }\end{array}$ & $\begin{array}{c}\text { Перевод } \\
\text { Е. М. Доброхотовой- } \\
\text { Майковой }\end{array}$ & Перевод В. Воседоя \\
\hline EustaceScrubb & Юстэс Вред & Юстэс Вред & $\begin{array}{c}\text { Юстейс Скрабб, по } \\
\text { прозвищу Бяка }\end{array}$ \\
\hline
\end{tabular}

При переводе данного примера О. Б. Бухина и Е. М. Доброхотова-Майкова используют транскрипцию для перевода имени «Eustace». Фамилия «Scrubb» является так называемой «говорящей» фамилией. «Scrubb» - альтернативное написание слова «Scrub», один из переводов которого - «раздражающий человек». При помощи приема модуляччии, переводчики передают данную фамилию как «Вред», что, на наш взгляд, является репрезентативным. В. Воседой использует альтернативный вариант транскрипции для имени, а фамилию транслитерирует и, к тому же, переводчик использует прием синтаксического расширения, указывая «по прозвишу Бяка», чтобы передать «говорящий» эффект фамилии на персонажа. Однако, стоит заметить, что данный роман - часть цикла книг и при первом появлении данного персонажа в одной из предыдущих частей, автор объясняет, что несмотря на такую «говорящую» фамилию, Юстас - хороший мальчик. Поэтому прозвище «Бяка» является неуместным и перевод В. Воседоя является нерепрезентативным.

Мы бы хотели предложить свой вариант перевода фамилии «Scrubb»- «Гадли». Такой вариант фамилии так же является «говорящим», но при этом, он больше похож на английскую фамилию (по аналогии с фамилией «Дадли»), чем фамилия «Вред», а герой, как известно, - англичанин.

\section{Прозвища}

\begin{tabular}{|c|c|c|c|}
\hline Оригинал & Перевод О. Б. Бухиной & $\begin{array}{c}\text { Перевод } \\
\text { Е. Моброхотовой- } \\
\text { Майковой }\end{array}$ & Перевод В. Воседоя \\
\hline Darkie & Темнолицый & черномазый & черномазый \\
\hline
\end{tabular}

При переводе вышеприведенного примера О. Б. Бухина использует конкретизацию, указывая, что темным является именно лицо, а также конверсию, преобразуя существительное в прилагательное. На наш взгляд, данный вариант перевода является репрезентативным. Е. М. Доброхотова-Майкова и В. Воседой используют эмфатизацию значения, поэтому перевод приобретает негативный оттенок. Стоит отметить, что переводчики употребляют данное слово не как имя собственное, а как нарицательное, таким образом, на наш взгляд, данный перевод является нерепрезентативным.

Мы бы хотели предложить свой вариант данного прозвища: «Черныш». Данный вариант передает лексическое значение и, при этом, содержит уменьшительноласкательный суффикс «ыш», что вполне соответствует уменьшительно-ласкательному суффиксу «іе» в слове-оригинале.

\section{Топонимы}

\begin{tabular}{|c|c|c|c|}
\hline Оригинал & Перевод О. Б. Бухиной & $\begin{array}{c}\text { Перевод } \\
\text { Е. М. Доброхотовой- } \\
\text { Майковой }\end{array}$ & Перевод В. Воседоя \\
\hline Calormen & Тархистан & Тархистан & Калормен \\
\hline
\end{tabular}

О. Б. Бухина и Е. М. Доброхотова-Майкова применяют к данному примеру замену, вероятно, обосновывая ее тем, что русскоязычному читателю не ясна задумка автора. Название вымышленной юго-восточной страны происходит от латинского 
«calor», что в переводе «жара». Русскоязычному читателю данная ассоциация не ясна, а вот название «Тархистан» напрямую ассоциируется со странами Ближнего Востока (Таджикистан, Узбекистан). Кроме того, в книге указывается название привилегированного сословия тюркской знати «тарханы» как название вельмож в «Calormen», отсюда и перевод названия данной страны как «Тархистан» На наш взгляд, переводческое решение является удачным и репрезентативным. В. Воседой транслитерирует название, что является репрезентативным способом перевода, однако мы считаем вариант О. Б. Бухиной и Е. М. Доброхотовой-Майковой наиболее удачным.

Астронимы

\begin{tabular}{|c|c|c|c|}
\hline Оригинал & $\begin{array}{c}\text { Перевод } \\
\text { О. Б. Бухиной }\end{array}$ & $\begin{array}{c}\text { Перевод } \\
\text { Е. М. Доброхотовой- } \\
\text { Майковой }\end{array}$ & Перевод В. Воседоя \\
\hline the SpearHead & Наконечник Копья & Остриё Копья & Рожон \\
\hline
\end{tabular}

При переводе вышеприведенного О. Б. Бухина и Е.М.Доброхотова-Майкова используют вариантные соответствия. Данный вариант перевода является репрезентативным. В. Воседой использует замену. На наш взгляд, данный вариант перевода репрезентативный и отлично подходит для названия звезды.

Подводя итог, стоит отметить, что в последнее время в теории перевода большое внимание уделяется прагматической адаптации, в рамках которой в процессе перевода допускается проводить определенные трансформации оригинала. Таким образом, согласно ученым в области теории перевода, антропонимы и топонимы переводят с помощью транскрипиии и транслитерации, а наиболее частотный перевод астронимов не выявлен, вследствие того, что данный ономастический класс еще недостаточно изучен.

В произведении «Последняя битва» антропонимы в подавляющем большинстве переводят с помощью транскрипции, однако, прозвища чаще всего калькируются. Это нужно для того, чтобы передать смысл данных прозвищ.

При переводе топонимов в произведении «Последняя битва» наиболее частотной трансформацией является калькирование, тогда как транскрипция и транслитерация зачастую делят между собой второе место. Мы считаем, что данное явление объясняется тем, что такие слова как «море», «река» и т.д. в данном произведении являются ономастической частью топонимов, а традиционный способ перевода таких слов ни что иное как калькирование.

При переводе астронимов в произведении «Последняя битва» переводчики чаще всего употребляли конверсию. Мы считаем, что данная закономерность обуславливается небольшим количеством примеров астронимов в произведении и не может выявить наилучшие способы перевода астронимов как ономастического класса.

На основе анализа, можно сделать вывод, что правильно донести до читателя культурные расхождения, зачастую отражаемые в именах собственных, - невероятно сложная задача, требующая определенных знаний, умений грамотно использовать переводческие трансформации, а также, нередко, творческого подхода.

$$
* * *
$$

1. Белозерова Ф. М. Антропонимы в английской фразеологии / Ф. М. Белозерова, Н. Л. Шомахер // Актуальные проблемы лингвистики. - Курган: 2000. - 1516 с.

2. Голев Н. Д., Дмитриева Л. М. Единство онтологического и ментального бытия топонимической системы (к проблеме когнитивной топонимики). URL : http://lingvo.asu.ru/golev/articles/z06.htm

3. Ермолович Д. И. Имена собственные на стыке языков и культур. / Д. И. Ермолович. - М.: Р.Валент, 2001. $-200 \mathrm{c}$.

4. Казакова Т. А. Практические основы перевода English - Russian. / Т. А. Казакова. - Изд-во «Союз», 2002. $-185 \mathrm{c}$.

5. Никонов В. А. Космонимия Поволжья // Ономастика Поволжья. Материалы III конференции по ономастике Поволжья. - Уфа: АН СССР; Башкирский филиал Института этнографии им. Н. Н. Миклухо-Маклая; Башкирский гос. ун-т, 1973. - 381 с. 